\title{
Prices and Excess Profits Taxes
}

\author{
By David Friday \\ University of Michigan
}

$I^{\mathrm{F}}$ F we may judge by the utterances of business men and of the press, the great mass of the American public believes that the excess profits tax has been largely responsible for the present high level of prices. Most of those who have spoken or written to this effect have thought it unnecessary to present proof in support of this conclusion; nor have they gone to the trouble to examine in detail the logic of the supposed causal connection. The report of the New York Chamber of Commerce states that "the effect of excess profits taxes on business enterprises and on the high cost of living is so evident as to require little explanation." May it not be possible that here, as in so many other instances in the history of political economy, the co-existence of two phenomena in time may have led to an erroneous conclusion with respect to their causal relations? The excess profits tax will no doubt be abandoned before the presidential election next fall. Its repeal will be conditioned upon considerations other than its effect upon prices, but it is incumbent upon the economist to examine critically the assertion that our first differential tax upon profits raised the price level by an amount greater than the tax.

The discussion of this question has proceeded with little reference to the facts concerning prices, profits, or taxes. These facts seem to the writer of such an unusual nature and so essen- tial even in a theoretical discussion of of the subject that he has decided to adopt the method employed by Sir William Petty in his Political Arithmetic. "The method I take to do this," said Sir William, "is not very usual; for instead of using only comparative and superlative words, I have taken the course to express myself in terms of number, weight or measure; to use only arguments of sense, and to consider only such causes as have visible foundations in nature."

Effect of Excess Profits Tax on the Rising Price Level

To one acquainted with the course of prices, profits and taxes, there are disturbing facts which do not harmonize easily, to say the least, with this glib theory which finds in the excess profits tax the chief cause of the rising price level. The price level did not wait for the advent of the excess profits tax in America. It started its ascent in July, 1915 and continued it blithely until in March, 1917 , the month previous to our entrance into the war, it stood at $\mathbf{1 6 0}$ per cent of the 1913 level. It continued its rise until July, 1917; at that time it stood at 185 . No excess profits tax law had yet been passed. The first law was passed in October, 1917 , but no material rise in price occurred for some months thereafter.

Under this first excess profits tax law the combined corporations of the United States paid 15.27 per cent of 
their reported net income in excess profits tax. After doing so, they had remaining net income equal to 210 per cent of the highest amount which they had earned in any pre-war year. For the year 1918 the excess profits rates were increased to the point where they absorbed approximately 25 per cent of the profits of that year. In 1919 the rates were materially reduced. As against $\$ 2,400,000,000$ of taxes in 1918 they yielded only one-half that amount in 1919. Prices in 1918 averaged 197 as against 175 in 1917 and 160 in the month previous to our entering the war. Despite the reduction of the tax in 1919 prices stood at 238 in December of that year. What we have, then, is a rise of 60 per cent in the price level before any excess profits tax was either levied or discussed, and a further rise of 27 points before the tax was passed. Then a comparatively slight rise in prices during the period of our highest excess profits taxes, and a renewed and rapid rise when the amount of the tax was cut in half. If one were satirically inclined, he might affect to look with apprehension upon a further reduction in the excess profits tax. This brief review of the course of prices and of taxes certainly casts serious doubt upon the assertion that "the effect of excess profits taxes on business enterprises and on the high cost of living is so evident as to require little explanation."

Nor does a study of the course of profits lend any support to the statement. that "for every $\$ 6.00$ or $\$ 7.00$ taken from the consumer, ostensibly for excess profits tax, only $\$ 1.00$ ever reaches the United States Treasury." It would follow from this that profits had increased, not merely by the amount of the tax, but that they had far outrun the amount collected by the government. But this is not what the statistics of profits disclose. They show profits as follows before deducting taxes:

$\begin{array}{lr}1913 \ldots \ldots \ldots \ldots \ldots & \$ 4,339,551,000 \\ 1914 \ldots \ldots \ldots \ldots \ldots & 3,940,000,000 \\ 1915 \ldots \ldots \ldots \ldots \ldots & 5,310,000,000 \\ 1916 \ldots \ldots \ldots \ldots \ldots & 8,766,000,000 \\ 1917 \ldots \ldots \ldots \ldots \ldots & 10,730,000,000 \\ 1918 \ldots \ldots \ldots \ldots \ldots & 9,500,000,000 \\ 1919 \ldots \ldots \ldots \ldots \ldots & 8,500,000,000\end{array}$

The figures for the years 1918 and 1919 are based upon estimates so carefully made that the final published figures will be but slightly different. After paying excess profits taxes the amount of net income remaining from 1917 to 1919 was as follows:
1917
$\$ 9,100,000,000$
1918
$7,100,000,000$
$1919 \ldots \ldots \ldots$
$7,300,000,000$

It is not true, therefore, that profits have increased since the imposition of the excess profits tax. Nineteen hundred and seventeen was the highwater mark of profits, and the tax was not imposed until the year had almost closed. After paying taxes the profits of 1918 and 1919 are far less than they were in 1916.

All of this reasoning concerning the effect of excess profits taxes upon prices rests upon one of two assumptions. Either it assumes that the state of demand during the last three years has been such that the public has been willing to pay practically any price and that sellers would not have charged high prices except under the necessities imposed upon them by the tax. This assumption certainly needs proving. It is not the sort of 
thing which can be accepted as a matter of course. The alternative assumption is that the profits of industry are such a small return upon the capital that the addition of a tax made it no longer worth while for the entrepreneur to remain in production. Therefore, unless the tax can be added to price, production is decreased and price rises in consequence. Now the figures already presented show that the profits of 1916 were already twice as high as those of any pre-war year, while those of 1917 were two and a half times as high. The following table shows that the tax fell heaviest upon industries like manufacturing, mining and trade. These are the industries which had profited most by the war. shows the net income for 30,892 corporations classified by industries and grouped according to the percentage which the corporations earned upon their invested capital. 'This table might well serve as a warning to those who desire the abolition of the excess profits tax. They were wise to confine themselves to "comparative and superlative words, instead of citing facts." For if the public is given these facts, fully and honestly, it will probably be impossible to abolish the tax.

\section{Relative Position of Supply and Demand}

Those who believe that all these movements in the price level were caused by the excess profits tax ascribe

TABLE I

Net Income and Excess Profits Taxes of all Corporations in the United States Pre-war and in 1916 and 1917 (Expressed in Millions)

\begin{tabular}{|c|c|c|c|c|}
\hline Year & Financial & $\begin{array}{c}\text { Railroads } \\
\text { and public } \\
\text { utilities }\end{array}$ & $\begin{array}{c}\text { Manufacturing, } \\
\text { mining, and } \\
\text { mercantile }\end{array}$ & Total \\
\hline 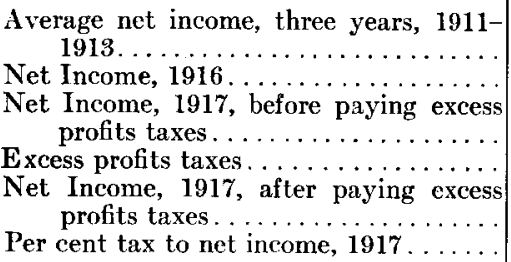 & $\begin{array}{r}\$ 459,154 \\
528,506 \\
962,860 \\
41,767 \\
921,093 \\
4.33 \%\end{array}$ & $\begin{array}{r}\$ 913,299 \\
1,541,076 \\
\\
1,303,824 \\
60,450 \\
1,243,374 \\
4.63 \%\end{array}$ & $\begin{array}{r}\$ 2,422,683 \\
6,696,327 \\
8,463,676 \\
1,536,531 \\
6,927,145 \\
18.15 \%\end{array}$ & $\begin{array}{r}\$ 3,795,136 \\
8,765,909 \\
10,730,360 \\
1,638,748 \\
9,091,612 \\
15.27 \%\end{array}$ \\
\hline
\end{tabular}

The actual percentage which various corporations earned upon their invested capital in 1917 is illuminating in this connection. It is also significant as throwing light upon the validity of our assumptions concerning the normal rate of profit. The next table has been prepared from the Senate Document entitled "Corporate Earnings and Government Revenues." It to that fiscal measure remarkable powers of levitation, for according to their analysis it produced an increase in price even when the tax was falling. Where the forces are so many and so complex as are those which lie at the foundation of the price level it is impossible to make convincing statistical proof of causal relations. We must supplement our investigation of facts, 
therefore, with a priori analysis. Here the economist's analysis of the forces which control price lends little color to the proposition that a differential tax on business profits will affect price. No doubt it still holds true that supply and demand are the only doors through which the effective causes of change can reach prices. We may safely assume, too, that the marginal pro- high point only under the stimulus of excess profits taxation.

\section{The Marginal Producer}

The tax can be added to price only if it falls on the marginal producer. But the marginal producer, if he be the one who is operating at the least profit, or at any profit not greater than 8 per cent, pays no tax. If he be a

TABLE II

Net Income of 30,892 Corporations in 1917

\begin{tabular}{|c|c|c|c|c|c|c|}
\hline $\begin{array}{l}\text { Percentage } \\
\text { of net } \\
\text { income to } \\
\text { capital }\end{array}$ & Financial & $\begin{array}{l}\text { Railroads } \\
\text { and public } \\
\text { utilities }\end{array}$ & $\begin{array}{l}\text { Transpor- } \\
\text { tation by } \\
\text { water }\end{array}$ & Agriculture & $\begin{array}{c}\text { Manufacturing, } \\
\text { mining, and } \\
\text { mercantile }\end{array}$ & Total \\
\hline Under $10 \%$ & $\$ 13,196,481$ & $\$ 349, \mathbf{1 8 9}, 634$ & $\$ 1,234,161$ & $\$ 11,406,299$ & $\$ 101,952,626$ & $\$ 476,979,201$ \\
\hline $10-15 \%$ & $29,993,941$ & $70,634,613$ & 476,988 & $12,329,659$ & $275,712,345$ & $389,147,546$ \\
\hline $15-20 \%$ & $6,086,476$ & $21,207,001$ & $\mathbf{3 4 2 , 6 0 9}$ & $11,727,481$ & $537,246,584$ & $576,610,151$ \\
\hline $20-25 \%$ & $4,997,479$ & $5,053,306$ & 795,384 & $8,918,816$ & $546,806,982$ & $566,571,967$ \\
\hline $25-30 \%$ & $1,098,866$ & 3,531 & $2,337,854$ & $6,846,975$ & $313,941,558$ & $324,228,784$ \\
\hline $30-40 \%$ & 767,187 & 30,486 & $7,000,892$ & $13,042,739$ & $668,613,578$ & $689,454,882$ \\
\hline $40-50 \%$ & 182,685 & & $3,728,476$ & $1,837,818$ & $1,183,859,40$ ? & $1,189,608,381$ \\
\hline $50-75 \%$ & 50,299 & & $4,496,975$ & $12,754,592$ & $275,655,773$ & $292,957,639$ \\
\hline $75-100 \%$ & 9,809 & & $21,542,242$ & 449,198 & $111,374,338$ & $133,375,587$ \\
\hline Over $100 \%$ & 123,018 & 52,229 & $1,395,374$ & 296,999 & $116,164,233$ & $118,031,853$ \\
\hline Tot & $\$ 56,506,241$ & $\$ 446,170,800$ & $\$ 43,350,955$ & $\$ 79,610,576$ & $\$ 4,131,327,419$ & $\$ 4,756,965,991$ \\
\hline
\end{tabular}

ducer will have an effect upon price, especially if he is tax free and if he contributes a substantial portion of the supply. Now with respect to the relative position of supply and demand, the situation during the last three years has probably been one in which the supply of goods could be but little increased. Further, the visible supply is far short of the demand at pre-war prices or even at the prices which prevailed when the excess profits tax was first imposed. The condition was one, therefore, in which it was possible to sell goods for a price largely in excess of cost and so at a profit above normal. In such a situation prices rose. But surely it is a bit bold and unwarranted to assume that prices will rise to this producer who was making more than 8 per cent and demands that larger amount because of opportunity cost, there is no escape for him by shifting to another industry, since he will be obliged to pay the excess profits tax in any other industry in which he may engage. It would seem pretty clear, then, that short of actual withdrawal from productive enterprise, the tax is not one which will affect supply in such manner as to increase price.

It is of course conceivable that the marginal producer may be of so little significance that his withdrawal from the field of production would not cause a material curtailment of supply, and that his presence does not affect 
competition sufficiently to influence prices and prevent their rise.

\section{Non-Tax-Paying Producers}

On the number and importance of non-tax-paying producers, we have, fortunately, some statistics. Nineteen hundred and eighteen was the year of the highest excess profits tax rates. A sample of 6,712 corporations shows that 3,064 of that number paid no excess profits tax whatever. These represented almost exactly one-third of the total invested capital of this group of corporations. They earned, on the average, 5.2 per cent. During the pre-war period, their capital was over 38 per cent of the total of this group, and they earned 7.4 per cent on their invested capital. It is very difficult to believe that these establishments representing 45 per cent of the total number and one-third of the total capital exercised no influence in competitive price making.

When we examine the remaining 3,648 corporations we find that 1,497 paid tax under the 30 per cent bracket, and that their total tax amounted to only 7.66 per cent of their net income. This group, together with those that paid no taxes, had over 60 per cent of the invested capital of these 6,712 corporations. Certainly their freedom from excess profits taxes should have given us abundant guarantee against the shifting of this tax.

But, as Hobson long since pointed out, it may be that neither of these groups is marginal, that the marginal man is found among those who made extraordinary profits. These are the men who have great resourcefulness and initiative and can easily shift to new fields. But shifting avails them nothing, as the excess profits tax applies to all fields of industry.

But one possibility still remains. May they not agree with the father of Huckleberry Finn. When the elder Finn was just entering upon the early stages of delirium tremens, he summed up his attitude toward our political institutions in general in the trenchant conclusion that "this is a hell of a government." May they not, similarly minded, withdraw from industry altogether, and from their citadel of past profits, accumulated in the days when there were no excess profits taxes, observe what the Wall Street Journal calls the "vampire-like" activities of the government.

\section{Taxes on Excess and War Profits}

The rate of profits which was sufficient to induce them to remain in business during the pre-war period would seem to be the best evidence on this point. Of the 6,712 corporations whose incomes were cited for 1918, 2,151 corporations paid practically all of the $\$ 121,039,923$ of taxes of this group, 1,497 paid $\$ 7,412,123$ and 3,064 paid no taxes. During the prewar period these 2,151 major taxpayers had earned $\$ 89,298,925$ on an invested capital of $\$ 603,000,000$. Evidently 15 per cent was sufficient to keep them in production during these pre-war years. During 1918 they earned a net income of $\$ 281,775$,190 on an invested capital of $\$ 1,060$,000,000 or 26.6 per cent on their invested capital before taxes. Of this the government took 43 per cent, leaving them approximately 15.2 per cent free and clear on an amount of capital 40 per cent larger. This additional capital largely represented war profits of 
the years preceding 1918 . 'These corporations would hardly be moved to withdraw from industry altogether by the workings of the excess profits tax.

But these taxes include not only those upon excess profits, but the war taxes as well. Since the war profits taxes were levied for only a single year and do not apply to the profits of 1919 or subsequent years, we must know the size of the excess profits tax alone and the ratio of that tax to capital. This amounted to $\$ 88,309,393$ for the 2,151 corporations, and constituted 31.3 per cent of the net income of these corporations, leaving them 18.2 per cent on their invested capital after paying taxes, as against 15 per cent in the pre-war period. Under the rates in force in $\mathbf{1 9 1 9}$ these corporations would have paid less than $\$ 58,000,000$, and would have remaining over 21 per cent on their invested capital.

Which of these groups of corporations, then, actually curtailed supply, or even threatened to do so, in such manner as to produce the rise in price? In other words, who shifted whose taxes? In the absence of monopoly it is extremely difficult to believe that any of them curtailed their supply. The buyer was placed at the mercy of the seller, not by the excess profits tax, but by the fact that the general supply of commodities had reached its maximum. There is absolutely nothing to prove that buyers would not have been just as completely at the seller's mercy if there had been no excess profits tax. Nor is there anything to prove that the seller would not have pursued his advantage as vigorously. That is an end for which sellers strive diligently and skilfully.

\section{Monopolistic Enterprises AND} Taxes

But what of monopoly? It is a well-known principle of price that prices of goods marketed under monopolistic conditions are fixed at the point where they will yield the highest net profit. It avails the monopolist nothing, therefore, to raise his price when he is confronted with an income tax. Any change in price will lower his tax, it is true, but it does so only by lowering his income. The amount that remains after payment of taxes will be less at the new price than at the former one. Of course, if a monopoly puts itself upon a fixed profit per unit, as some automobile manufacturers are said to do, then it may be that the imposition of an excess profits tax will produce an increase in price. But this is only because the monopolist had not pushed his advantage to its logical conclusion before.

In cases of monopolistic enterprises or of other enterprises which are making high percentage of profit, the working of the excess profits tax actually tends to stimulate the investment of new capital in the old enterprise and thus to increase the supply and lower the price of the product. Moreover, this is the more true as the maximum rates of taxation are increased. For the additional invested capital will add to the ultimate net income available for distribution, not only the amount which is earned from the sale of the additional product, say 5 per cent, but it will increase the exemption by 8 per cent of the invested capital and so reduce the amount which is subject to the highest rates. Thus, if a company on an invested capital of $\$ 10,000,000$ makes a net income of 
$\$ 2,500,000$ (or 25 per cent) its excess profits taxes under the 1919 rates would be $\$ 439,400$ and its net income after taxes $\$ 2,060,600$. Now assume that the investment of $\$ 2,000,000$ of additional capital will increase its net income by $\$ 100,000$ or 5 per cent on its additional capital. This return would probably not be sufficient inducement for the investment. But an excess profits tax at even the low rates of 20 and 40 per cent which prevailed in 1919 will now be only $\$ 367$,400 on the net income of $\$ 2,600,000$, leaving \$2,232,600 after payment of taxes. If we compare this amount with the amount remaining originally, we find that the net income left to the corporation has increased by $\$ 172,000$, or 8.6 per cent on the additional invested capital of $\$ 2,000,000$. This would probably be a sufficient inducement for the new money, as it is well above the going rate of interest. This effect of additional invested capital has been recognized by those who have advised corporations in excess profits tax matters, and has been noted by J. C. Stamp in a recent article in the Economic Journal.

\section{Excess Profits Tax not Cause of InCReased Prices}

Neither the statistical facts nor the implications of economic law support the conclusion that the excess profits tax has been responsible for the increase in price which we have witnessed during the last five years. The most that can be said for it is that the tax may have given some seller the courage to move his price up a little earlier, or a little farther, than he would otherwise have done. But not even this much can be conceded for the rise of 60 points which occurred between July, 1915, and March, 1917.

\section{Change of Institutions and Attitude}

To trace the effect of the complex and tangled causes that have produced the present price situation is a long and arduous task. In the writer's opinion any such explanation must take as its point of departure the complete revaluation of ends which took place in the European mind when the nations went to war. It must conclude with an analysis of the present inefficiency of labor, a factor which increases the cost of the labor element in production far more than is indicated by the mere rise of wage scales per hour or per day. Between the beginning and the end of the war a whole series of institutions and of human attitudes has been wrecked. The gold standard, conservative banking policy, a private economy which set store by a constant power to demand the things needed for a customary class standard of living, our mental attitude toward national indebtedness, our conception of what constitutes an honest day's work for an honest day's pay; every one of these phrases stood at the beginning of the European war for a definite part of the institutional situation within the confines of which the industrial life of the people moved. Every one of these institutions has been radically changed. In the story of that change lies the explanation for our new price level. 